J. Amer. Soc. Hort. Sci. 115(2):288-293. 1990.

\title{
Relationship of Photosynthesis and Harvest Index to Sweet Potato Yield
}

\author{
Ajmer S. Bhagsari \\ Agricultural Research Station, Fort Valley State College, Fort Valley, GA 31030 \\ Doyle A. Ashley \\ Department of Agronomy, University of Georgia, Athens, GA 30602 \\ Additional index words. Ipomoea batatas, canopy photosynthesis, single-leaf net photosynthesis, translocation, leaf area \\ index, sink
}

\begin{abstract}
Field experiments with 15 sweet potato [Ipomoea batatas L. (Lam.)] genotypes were conducted to study the physiological basis of yield in 1981 and 1982. The leaf area index differed significantly among the sweet potato genotypes during early and late phases of growth, hut showed an inconsistent relationship with yield. Single leaf net photosynthesis ranged from 0.74 to $1.12 \mathrm{mg} \mathrm{CO} / \mathrm{m}$ per sec. Canopy photosynthesis for sweet potato genotypes

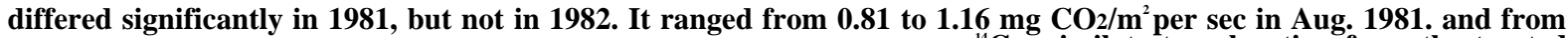
0.63 to $0.88 \mathrm{mg} \mathrm{CO} / \mathrm{m}^{2}$ per sec in 1982 . Four hours after "C-labeling, ${ }^{14} \mathrm{C}$-assimilate translocation from the treated leaf ranged from $21 \%$ to $46 \%$, but did not differ significantly among the genotypes. At final harvest, harvest index [HI, defined as (storage root yield/total biological yield) $x$ 100] of the genotypes varied from $43 \%$ to $77 \%$ and $31 \%$ to $75 \%$ for 1981 and 1982, respectively. Canopy photosynthesis during September was significantly correlated with storage root dry matter yield $(r=0.54 *)$ in 1981 and with phytomass (above-ground biomass plus storage roots) ( $r$ $=0.60 *)$ in 1982. Both phytomass and HI were significantly correlated with storage root matter yield. Canopy photosynthetic evaluation of sweet potato germplasm may be-more relevant when the storage root sinks are at an advanced stage of development. Our study suggests that yield is poorly predicted by Pn, particularly when the genotypes have different leaf sizes.
\end{abstract}

More than $90 \%$ of the carbon accumulated by plants is photosynthetically assimilated by the leaves (Zelitch, 1982). Singleleaf net photosynthesis (Pn) generally is not correlated with yield (Bhagsari and Brown, 1986; Bhagsari, 1981; Gifford and Evans, 1981; Zelitch, 1982). The reasons for this lack of correlation are not known, but the negative correlation of Pn with the area of the leaf used for Pn measurements may be a contributing factor (Austin et al., 1982; Bhagsari and Brown, 1986; Gifford and Evans, 1981). Hence, Pn of single leaves in a crop canopy may be too variable to accurately reflect the performance of all leaves in the canopy. The mean Pn for 'Centennial' sweet potato was lower than for 20 other genotypes, except one, but it ranked third in storage root yield (Bhagsari and Harmon, 1982). The area per leaf for 'Centennial' was higher than that for other sweet potato genotypes (Bhagsari and Brown, 1986; Bhagsari and Harmon, 1982).

Translocation rates of ${ }^{14} \mathrm{C}$-assimilate varied among genotypes of peanut (Arachis hypogaea L.) (Bhagsari and Brown, 1976), potato (Solanum tuberosum L.) (Gawronska et al., 1984), and several other plant species (Hofstra and Nelson, 1969). The Pn was positively correlated with ${ }^{14} \mathrm{C}$-assimilate translocation rates of peanut (Bhagsari and Brown, 1976) and many other $\mathrm{C}_{3}$ and $\mathrm{C}_{4}$ plants (Hofstra and Nelson, 1969).

Crop yields may be impacted by canopy photosynthesis (CPn), harvest index $(\mathrm{HI})$ [(storage root yield/total biological yield) $\times$ 100] or both. Soybean [Glycine max (L.) Merr.] seed yield and CPn were significantly related (Harrison et al., 1981; Wells et al., 1982). The superior yield of 'Houser' wheat (Triticum aestivum L.) over 'Honor' was attributed to the difference in their HI (Gent and Kiyomoto, 1985).

Yield improvements for wheat and peanut have been attributed mainly to the increase in HI (Austin et al., 1982; Gifford

Received for publication 17 Jan. 1989. The cost of publishing this paper was defrayed in part by the payment of page charges. Under postal regulations, this paper therefore must be hereby marked advertisement solely to indicate this fact. et al., 1984; Zelitch, 1982). Dry matter partitioned to fruit in peanut ranged from $23 \%$ for 'Dixie Runner', a low-yielding cultivar, to $51 \%$ for 'Early Bunch', a high-yielding cultivar (Duncan et al., 1978). The HI for Triticum spp. ranged from $5 \%$ to $51 \%$ (Austin et al., 1982). A significant variation in HI of 24 soybean genotypes was reported, but HI did not show a consistent relationship to yield (Schapaugh and Wilcox, 1980). Similarly, the HI of nine dry bean (Phaseolus vulgaris L.) genotypes ranged from $44 \%$ to $55 \%$ and also showed no relationship to yield (Peet et al., 1975).

A wide variation in $\mathrm{HI}$ of root and tuber crops has been reported. The HI for potato ranged from $65 \%$ to $80 \%$ (Victorio et al., 1986), that for sweet potato from $1.2 \%$ to $56 \%$ (Bhagsari and Harmon, 1982), 37\% to $81 \%$ (Bouwkamp and Hassam, 1988), $64 \%$ to $84 \%$ (Lowe and Wilson, 1974) and $38 \%$ to $88 \%$ (Enyi, 1977). For cassava (Manihot esculenta Crantz.), the HI ranged from $25 \%$ to $60 \%$ (Kawano et al., 1978).

The objective of this study was to determine the relationship of leaf and canopy photosynthesis rates, leaf area, and harvest index to sweet potato storage root yield.

\section{Materials and Methods}

Plant material. Field experiments were conducted in 1981 and 1982 at the Agricultural Research Station, Fort Valley State College, Ga. using 15 sweet potato genotypes for each year. Genotype selection was based on Pn and other physiological data from previous studies at this location (Bhagsari and Harmon, 1982; Bhagsari, 1981). The soil for this study was a Norfolk loamy sand (fine-loamy, siliceous, thermic Typic Paleudult). Two equal fertilizer applications, one during land preparation and a second before hilling [=45 days after planting (DAP)] provided totals of $50 \mathrm{~N}-44 \mathrm{P}-123 \mathrm{~K}$ (in $\mathrm{kg} \cdot \mathrm{ha}-{ }^{\mathrm{l}}$ ), respectively.

The experimental design was a randomized complete block with four replications. Slips were planted 25 and 26 May 1981 and 19 and 20 May 1982 in three-row plots $8.0 \times 3.6 \mathrm{~m}$, with $1.2-\mathrm{m}$ spacing between beds and $0.3 \mathrm{~m}$ between plants. An 
application of $N$, N-dimethyl-a-phenylbenzeneacetamide (diphenamid) was made at $2.0 \mathrm{~kg} \cdot \mathrm{ha}^{-1}$ after transplanting the slips. Sprinkler irrigation was used as needed. In addition, $25 \mathrm{~mm}$ of water was applied 1 day before the photosynthesis measurements to minimize water stress.

Plant samples. Two plants per plot were harvested" every 2 weeks from 30 June 1981 until final harvest in October for growth analyses. At first sampling, one border plant in each row was discarded from the sample to avoid border effects. At each subsequent sampling, two plants per plot were harvested in the same row direction.

Samples were taken from 13 to 19 July and from 30 Aug. to 2 Sept. 1982. A wooden frame $(0.6 \times 1.2 \mathrm{~m})$, with a sharp blade attached on each bottom side, was used to separate the foliage. The frame was placed at random in the middle row of each plot and all the phytomass, including dry leaves and branches, was collected. At final harvest, the plants in the area used to determine CPn were harvested separately. Plants were separated into leaves, petioles, stems, and storage roots. Leaf area was measured with a leaf-area meter (Model LI 3100, LI-COR, Lincoln, Neb.). Plant materials were dried at 60C and dry weights recorded. For growth analysis, all roots $1.0 \mathrm{~cm}$ or more in diameter were considered storage roots. All roots $2.5 \mathrm{~cm}$ and larger in diameter were included in root yield at final harvest.

Canopy photosynthesis. A $1.4 \times 1.2 \mathrm{~m}$ rectangular concrete base was embedded in the soil around four plants of the middle row of each experimental plot after hilling. The concrete base was $10 \mathrm{~cm}$ wide with a $3.5-\mathrm{cm}$ groove on the top four sides. Before placing the photosynthesis chamber on the concrete base, water was added to the groove to make the system air-tight during CPn measurement. Four steel rods, each $0.6 \mathrm{~m}$ high, were fixed in the concrete frame (enclosing about a $1-\mathrm{m}^{2}$ area) to support poultry mesh for containment of sweet potato vines. Periodically, the vines were checked and placed back within the poultry mesh confinement.

A plexiglass photosynthetic chamber, $1.3 \times 1.1 \mathrm{~m}$ and 0.7 $\mathrm{m}$ high and fitting the groove in the concrete base was used to measure $\mathrm{CPn}$. The $\mathrm{CPn}$ was measured with an infrared $\mathrm{CO}_{2}$ analyzer (Model 215 B; Beckman Instruments, Fullerton, Calif.) in full sunlight (above $1500 \mu \mathrm{mol} \cdot \mathrm{s}^{-1} \cdot \mathrm{m}^{-2}$ between 1100 and $1500 \mathrm{HR}$ from 17 to $24 \mathrm{Aug}$. and from 8 to 10 Sept. 1981, and from 15 to 17 Sept. 1982. Diurnal CPn for 'Centennial' was determined at 2-hr intervals on 8 Aug. 1981 between 0700 and $1900 \mathrm{HR}$. The details for chamber construction and CPn measurement have been given by Bhagsari et al. (1988).

Single-leaf net photosynthesis. The Pn was determined only from 21 to 24 Sept. 1981 in an open system with an infrared analyzer between 1100 and $1500 \mathrm{HR}$ at photosynthetic photon flux above $1500 \mu \mathrm{mol} \cdot \mathrm{s}^{-} \cdot \mathrm{m}^{-}{ }^{2}$. A fully expanded, mature, and attached second or third leaf from the top was enclosed in a plexiglass chamber $(0.23 \times 0.22 \mathrm{~m}$ and $0.07 \mathrm{~m}$ high $)$. The leaf temperature was maintained at $30 \pm 2 \mathrm{C}$. Other Pn measurement details have been reported previously (Bhagsari and Harmon, 1982; Bhagsari, 1981).

${ }^{14} \mathrm{C}$-assimilate translocation. To determine ${ }^{14 \mathrm{C} \text {-assimilate }}$ translocation, the same 15 genotypes used for CPn measurement were planted 26 May 1981, on 15-cm-high ridges, $8.0 \mathrm{~m}$ long and $2.4 \mathrm{~m}$ apart with $1.5-\mathrm{m}$ spacing between plants. The experimental design was a randomized complete block with four replications. Cultural practices were the same as for the other sweet potato experiment.

One leaf of each genotype per replication was exposed to ${ }^{14} \mathrm{CO}_{2}$ between 1100 and 1400 HR on sunny days between 8 to
15 July. The leaves were exposed to ${ }^{14} \mathrm{CO}_{2}$ in a plexiglass chamber consisting of two parts. The upper part, $0.20 \times 0.23 \mathrm{~m}$ and $0.06 \mathrm{~m}$ high, had a copper coil in the bottom for circulating cold water to maintain temperature at $30 \pm 2 \mathrm{C}$. The lower part, $0.14 \times 0.09 \mathrm{~m}$ and $0.10 \mathrm{~m}$ high, was glued to the bottom of the upper chamber and housed a small electric motor. A small fan, supported on the electric motor shaft extending to the upper chamber, provided air turbulence during ${ }^{14} \mathrm{CO}_{2}$ labeling. A nylon thread network across the lid and in the body of the upper chamber (above the fan) held the leaf in a horizontal position.

A plastic container, having $1 \mathrm{ml}$ of an aqueous solution containing $1.85 \mathrm{MBq}$ of $\mathrm{NaH}^{14} \mathrm{CO}_{3}$ with specific activity of 2.82 $\mathrm{MBqžmM}^{-1}$, was placed in one corner of the upper chamber. After enclosing one leaf into the upper chamber, $1 \mathrm{ml}$ of $6 \mathrm{~N}$ HCI was injected hypodermically through a serological stopper into the $\mathrm{NaH}^{14} \mathrm{CO}_{3}$ solution to generate ${ }^{14} \mathrm{CO}_{2}$. The leaf was removed from the chamber after $15 \mathrm{~min}$ of exposure to ${ }^{14} \mathrm{CO}_{2}$ and was allowed to photosynthesize in ambient conditions for $4 \mathrm{hr}$. After harvest, each plant was divided into: 1) treated leaf, 2) all other leaves, 3) petioles and branches, and 4) storage roots. The plant material was freeze-dried and ground to pass a 20-mesh screen.

A Thomas-Ogg infrared ignition flask (Model II, Arthur H. Thomas Co., Philadelphia) was used to release ${ }^{14} \mathrm{C}$ from the plant material. The procedures for igniting the labeled tissue, and the composition of the cocktail for absorption and recovery of ${ }^{14} \mathrm{CO}_{2}$, have been described by Bhagsari and Brown (1976). Radioactivity was determined by liquid scintillation counting. Carbon-14 recovered from all plant parts, except the treated leaf, was assumed to be translocated.

Data analysis. All data were treated statistically using analysis of variance procedures. The correlations between plant traits were calculated using the treatment means for each genotype.

\section{Results and Discussion}

Diurnal trends in canopy photosynthesis. The diurnal CPn for 'Centennial' on 8 Aug. 1981 was $0.16 \pm 0.08 \mathrm{mg} \mathrm{C0} / \mathrm{m}^{2}$ per sec between 0700 and $0800 \mathrm{HR}$, but increased 5-fold during the next hour, with the rate reaching a maximum at about $1300 \mathrm{HR}$ (Table 1). The CPn was similar between 1300 and $1600 \mathrm{HR}$, but declined thereafter. The canopy light compensation point, indicating no net $\mathrm{CO}_{2}$ uptake, was reached at photosynthetic photon flux of $=183 \mu \mathrm{mol} \cdot \mathrm{s}^{-1} \cdot \mathrm{m}-2$ between 1930 and 2000 HR. The subsequent measurements of genotypic CPn were made between 1100 and $1500 \mathrm{HR}$.

Leaf area index. The LAI differed significantly during the early growth phase in 1981 and during the late growth stage in 1982 (Table 2). The LAI ranged from 0.74 to 1.97 at 35 DAP

Table 1. Diurnal trends in canopy photosynthesis of 'Centennial' sweet potato, 8 Aug. 1981.

\begin{tabular}{ccc}
\hline \hline $\begin{array}{c}\text { Time interval } \\
(\mathrm{HR})\end{array}$ & $\begin{array}{c}\text { Light intensity } \\
\left(\mu \mathrm{mol} \cdot \mathrm{s}^{-1} \cdot \mathrm{m}^{-2}\right)\end{array}$ & $\begin{array}{c}\text { Photosynthesis }^{2} \\
\left(\mathrm{mg} \mathrm{CO}_{2} / \mathrm{m}^{2} \text { per see }\right)\end{array}$ \\
\hline $0700-0800$ & 286 & $0.16 \pm 0.08$ \\
$0900-1000$ & 858 & $0.78 \pm 0.17$ \\
$1100-1200$ & 1210 & $1.10 \pm 0.08$ \\
$1300-1400$ & 1562 & $1.31 \pm 0.06$ \\
$1500-1600$ & 1518 & $1.26 \pm 0.06$ \\
$1700-1800$ & 1089 & $0.98 \pm 0.06$ \\
$1900-2000$ & 183 & $0.06 \pm 0.06$ \\
\hline
\end{tabular}

${ }^{2}$ Values are means of four replicates \pm SD. 
Table 2. Leaf area index and single leaf ( $\mathrm{Pn})$ and canopy net photosynthesis (CPn; ground-area basis) of selected sweet potato genotypes at various days after planting (DAP).

\begin{tabular}{|c|c|c|c|c|c|c|c|c|c|}
\hline \multirow[b]{3}{*}{ Genotype } & \multicolumn{5}{|c|}{ Leaf area index ${ }^{2}$} & \multirow{2}{*}{$\begin{array}{c}\mathrm{Pn} \\
1981 \\
\end{array}$} & \multicolumn{3}{|c|}{$\mathrm{CPn}$} \\
\hline & \multicolumn{2}{|c|}{1981} & \multicolumn{3}{|c|}{1982} & & \multicolumn{2}{|c|}{1981} & 1982 \\
\hline & $\begin{array}{c}30 \\
\text { June } \\
(35 \\
\text { DAP })\end{array}$ & $\begin{array}{c}13-16 \\
\text { July } \\
(51 \\
\text { DAP) }\end{array}$ & $\begin{array}{c}13-19 \\
\text { July } \\
(60 \\
\text { DAP) }\end{array}$ & $\begin{array}{c}30 \text { Aug.- } \\
2 \text { Sept. } \\
\text { (105 } \\
\text { DAP) }\end{array}$ & $\begin{array}{l}8-10 \\
\text { Oct. } \\
(143\end{array}$ & $\begin{array}{l}21-24 \\
\text { Sept. } \\
\text { (121 } \\
\text { DAP) }\end{array}$ & $\begin{array}{c}17-24 \\
\text { Aug. } \\
(90 \\
\text { DAP) }\end{array}$ & $\begin{array}{c}8-10 \\
\text { Sept. } \\
(107 \\
\text { DAP) }\end{array}$ & $\begin{array}{l}15-17 \\
\text { Sept. } \\
(120 \\
\text { DAP) }\end{array}$ \\
\hline & \multicolumn{5}{|c|}{ Ratio } & \multicolumn{4}{|c|}{$m g \quad C O \_m^{2}$ per sec } \\
\hline Georgia Jet & 1.97 & 4.00 & 3.68 & 3.29 & 2.81 & 0.92 & 0.99 & 0.84 & 0.87 \\
\hline Lo 323 & 1.81 & 2.34 & 3.71 & 2.91 & 3.85 & 0.79 & 0.94 & 0.91 & 0.75 \\
\hline $71-63-1$ & 1.62 & 3.39 & 3.43 & 3.07 & 4.29 & 0.80 & 0.92 & 0.76 & 0.63 \\
\hline Centennial & 1.60 & 2.90 & 3.38 & 3.40 & 3.51 & 0.76 & 1.16 & 1.01 & 0.79 \\
\hline Georgia Red & 1.54 & 3.24 & 3.54 & 1.91 & 2.17 & 0.85 & 0.88 & 0.72 & 0.69 \\
\hline Acadian & 1.50 & 1.93 & 4.32 & 3.70 & 2.68 & 0.88 & 0.96 & 0.84 & 0.77 \\
\hline $75-96-1$ & 1.47 & 2.34 & 4.26 & 2.62 & 3.18 & 1.12 & 1.01 & 1.00 & 0.80 \\
\hline L7-3 & 1.43 & 2.36 & 3.23 & 2.27 & 2.70 & 0.82 & 1.01 & 0.66 & 0.65 \\
\hline Travis & 1.41 & 2.90 & 2.84 & 2.85 & 3.40 & 0.95 & 1.12 & 0.90 & 0.71 \\
\hline Earlyport & 1.37 & 2.54 & 3.56 & 2.78 & 3.34 & 0.77 & 1.05 & 0.87 & 0.81 \\
\hline Carolina Nugget & 1.36 & 2.51 & 3.45 & 3.58 & 3.13 & 0.96 & 0.96 & 0.98 & 0.84 \\
\hline Carver & 1.13 & 2.50 & 3.32 & 2.53 & 2.89 & 0.82 & 1.12 & 0.91 & 0.88 \\
\hline Coastal Sweet & 0.89 & 2.87 & 3.50 & 2.40 & 2.79 & 0.74 & 0.81 & 0.78 & 0.64 \\
\hline Nemagold & 0.80 & 2.14 & 3.38 & 2.94 & 2.84 & 0.84 & 0.87 & 0.88 & 0.77 \\
\hline OK-8-85 & 0.74 & 2.09 & 2.17 & 2.99 & 2.34 & 0.76 & 0.94 & 1.03 & 0.71 \\
\hline$\% \mathrm{C} \mathrm{V}$ & 30.3 & 29.5 & 29.5 & 29.6 & 21.5 & 12.9 & 11.6 & 14.7 & 21.1 \\
\hline LSD 5\% & 0.59 & 1.12 & NS & 1.39 & 0.94 & 0.18 & 0.19 & 0.22 & N S \\
\hline
\end{tabular}

${ }^{2}$ Ratio = ratio of leaf area to land area.

${ }^{\mathrm{NS}}$ Nonsignificant.

and nearly doubled in the following 2 weeks. During early growth, 'Georgia Jet' maintained higher LAI than six other genotypes in 1981. During 1982, the LAI ranged from 1.91 to 3.70 at 105 DAP and from 2.17 to 4.29 at 143 DAP final harvest.

Single-leaf net photosynthesis. The Pn for sweet potato genotypes, determined only during 1981, differed significantly (Table -2). The Pn for selection 75-96-1 was significantly higher than for other genotypes, except 'Travis' and 'Carolina Nugget'. The mean Pn ranking of 'Centennial', the second lowest, is similar to that in our previous report (Bhagsari and Harmon, 1982).

Canopy photosynthesis. The CPn among sweet potato genotypes varied significantly in 1981, but not in 1982 (Table 2). The CPn ranged from 0.81 to 1.16 and 0.66 to $1.03 \mathrm{mg} \mathrm{CO}_{2} /$ $\mathrm{m}^{2}$ per sec. during Aug. and Sept. 1981, respectively. The CPn was probably lower in 1982 than for 1981 because of late measurement.

The Pn for 'Centennial' was generally lower than for the other genotypes, just as reported earlier (Bhagsari and Harmon, 1982). However, CPn for 'Centennial' ranked first and second during Aug. and Sept. 1981 and sixth in 1982. This variation suggests that photosynthetic evaluation based on Pn and CPn may differ for some genotypes. There also was a large genotypic variation in sweet potato leaf size, which has been shown to be negatively correlated with Pn (Bhagsari and Brown, 1986). The inverse ranking of 'Centennial' Pn and CPn (Table 2) might be attributed to its large leaf size $\left(\approx 150-200 \mathrm{~cm}^{2}\right)$. Thus, photosynthetic evaluation of sweet potato and other crop plants having differing leaf sizes should be based on CPn rather than Pn.

Storage root development patterns. Significant variation was observed in sweet potato storage root dry matter accumulation during 1981 (Table 3). The genotype OK 8-85 had a relatively high storage root dry matter yield until about 65 DAP. During
mid-August, 'Georgia Jet' had higher storage root dry matter than many of the other genotypes. 'Acadian' and L7-3 developed a large portion of their storage root weight during September. Photosynthetic rates are generally affected by sink demand; therefore, the variations in storage root development rates probably affected the photosynthetic response of the genotypes in our study.

Harvest index and yield. The range in $\mathrm{HI}$ at first sampling during mid-July was similar for 1981 and 1982 (Table 4). During 1981, the HI ranged from $43 \%$ to $77 \%$ at final harvest 135 DAP. About 105 DAP, the HI for 1982 ranged from $22 \%$ to 62\%. The HI at final harvest was lower in 1982 than in 1981 for about one-half the genotypes. For both years, HI of 'Acadian' was lower than for most other genotypes. Although 'Acadian' was introduced as a high-yielding cultivar during the 1950s, the poor HI and yield response may have been caused by deleterious mutations common in sweet potato. Phytomass ranged from 7.1 to 13.8 and 6.7 to $17.0 \mathrm{Mg} \cdot \mathrm{ha}^{-1}$ at final harvest during 1981 and 1982, respectively (Table 4).

Both fresh and dry matter yields differed significantly among sweet potato genotypes in each experiment (Table 5). Fresh storage root yield was higher for 'Georgia Jet', Lo 323, and 'Travis' than other genotypes during 1981. However, final dry matter storage root yields of these genotypes were similar to selection 75-96-1 and many other genotypes because the latter had a high percent dry matter in storage roots.

Genotypes differed significantly for number of storage roots per plant for both experiments (Table 5). The mean number of storage roots was similar for both experiments. 'Acadian' had a relatively low number of storage roots, but did not differ significantly from some of the other genotypes.

${ }^{14} \mathrm{C}$.assimilate translocation. The percent of ${ }^{14} \mathrm{C}$ translocation from the treated leaf did not differ significantly among the sweet 
Table 3. Storage root dry weights of 15 sweet potato genotypes on successive harvest dates, $1981 .^{2}$

\begin{tabular}{lcccccc}
\hline \hline Genotype & 13-16 July & 27-30 July & 12 Aug. & 26 Aug. & 9 Sept. & 24 Sept. \\
(51 DAP) & (65 DAP) & (79 & DAP) & (92 DAP) & (107 DAP) & (122 DAP) \\
\hline Georgia Jet & 16.6 & 45.9 & 166 & 206 & 265 & 261 \\
Lo 323 & 10.7 & 29.9 & 79 & 131 & 253 & 231 \\
71-63-1 & 9.9 & 26.7 & 80 & 135 & 262 & 247 \\
Centennial & 12.8 & 56.1 & 93 & 155 & 197 & 265 \\
Georgia Red & 8.2 & 9.3 & 60 & 153 & 210 & 203 \\
Acadian & 8.6 & 13.4 & 67 & 48 & 90 & 180 \\
75-96-1 & 9.6 & 14.2 & 89 & 152 & 240 & 237 \\
L7-3 & 0.3 & 5.0 & 12 & 34 & 107 & 184 \\
Travis & 8.8 & 11.5 & 54 & 129 & 224 & 265 \\
Earlyport & 7.7 & 16.7 & 93 & 183 & 184 & 208 \\
Carolina Nugget & 16.6 & 34.2 & 131 & 167 & 204 & 241 \\
Carver & 11.6 & 27.8 & 119 & 150 & 205 & 274 \\
Coastal Sweet & 3.6 & 20.8 & 66 & 130 & 125 & 188 \\
Nemagold & 10.2 & 11.6 & 46 & 121 & 189 & 234 \\
OK-8-85 & 20.2 & 84.5 & 117 & 112 & 216 & 259 \\
& & & & & & \\
Mean & 10.4 & 27.2 & 85 & 134 & 198 & 232 \\
LSD 5\% & $\mathrm{N} \mathrm{S}$ & 39.9 & 53 & 91 & 110 & N S \\
\hline
\end{tabular}

${ }^{2} \mathrm{DAP}=$ days after planting.

${ }^{\text {NS }}$ Nonsignificant.

Table 4. Harvest index and total phytomass of sweet potato genotypes on successive harvest dates. ${ }^{2}$

\begin{tabular}{|c|c|c|c|c|c|c|c|}
\hline \multirow[b]{5}{*}{ Genotype } & \multicolumn{5}{|c|}{ Harvest index } & \multicolumn{2}{|c|}{ Phytomass } \\
\hline & \multicolumn{2}{|c|}{1981} & \multicolumn{3}{|c|}{1982} & \multirow{4}{*}{$\begin{array}{c}1981 \\
2-8 \\
\text { Oct. } \\
\text { (135 } \\
\text { DAP) }\end{array}$} & \multirow{4}{*}{$\begin{array}{l}1982 \\
8-10 \\
\text { Oct. } \\
\text { (143 } \\
\text { DAP) }\end{array}$} \\
\hline & $13-16$ & $2-8$ & $13-19$ & 30 Aug.- & $8-10$ & & \\
\hline & $\begin{array}{c}\text { July } \\
(51\end{array}$ & $\begin{array}{l}\text { Oct. } \\
(135\end{array}$ & $\begin{array}{c}\text { July } \\
(60\end{array}$ & $\begin{array}{c}2 \text { Sept. } \\
(105\end{array}$ & $\begin{array}{l}\text { Oct. } \\
\text { (143 }\end{array}$ & & \\
\hline & DAP) & DAP) & DAP) & DAP) & DAP) & & \\
\hline & \multicolumn{5}{|c|}{$\%$} & \multicolumn{2}{|c|}{$M g \cdot h a^{-1}$} \\
\hline Georgia Jet & 11.6 & 73.8 & 12.8 & 61.4 & 75.0 & 9.8 & 15.2 \\
\hline Lo 323 & 11.0 & 65.2 & 5.1 & 57.6 & 67.2 & 10.4 & 12.1 \\
\hline $71-63-1$ & 11.3 & 65.1 & 16.8 & 47.4 & 51.5 & 12.1 & 10.2 \\
\hline Centennial & 13.0 & 66.8 & 12.7 & 51.8 & 48.2 & 10.6 & 12.1 \\
\hline Georgia Red & 7.1 & 75.4 & 6.6 & 56.7 & 66.4 & 10.4 & 9.3 \\
\hline Acadian & 9.1 & 43.5 & 2.1 & 21.8 & 31.2 & 7.1 & 6.8 \\
\hline $75-96-1$ & 7.8 & 64.8 & 3.6 & 36.1 & 60.7 & 12.7 & 17.0 \\
\hline L7-3 & 2.7 & 49.2 & 4.1 & 44.7 & 52.5 & 12.0 & 10.9 \\
\hline Travis & 10.0 & 72.5 & 16.7 & 41.4 & 40.2 & 10.1 & 6.7 \\
\hline Earlyport & 8.6 & 67.9 & 26.3 & 54.0 & 63.5 & 13.8 & 14.7 \\
\hline Carolina Nugget & 15.6 & 73.0 & 14.6 & 42.1 & 58.1 & 11.8 & 13.8 \\
\hline Carver & 11.5 & 68.2 & 23.6 & 60.5 & 61.3 & 12.9 & 13.5 \\
\hline Coastal Sweet & 3.2 & 55.6 & 3.2 & 42.1 & 57.6 & 7.2 & 10.2 \\
\hline Nemagold & 14.4 & 71.8 & 8.7 & 36.1 & 56.6 & 12.4 & 10.1 \\
\hline OK-8-85 & 21.7 & 77.4 & 25.7 & 62.3 & 75.1 & 11.7 & 11.5 \\
\hline$\% \mathrm{CV}$ & 67.3 & 8.6 & 56.5 & 27.2 & 19.5 & 12.6 & 19.4 \\
\hline LSD $5 \%$ & $\mathrm{n} \mathrm{s}$ & 9.4 & 9.8 & 18.5 & 16.1 & 2.3 & 3.2 \\
\hline
\end{tabular}

potato genotypes $4 \mathrm{hr}$ after labeling, despite the 2-fold differences observed in ${ }^{14} \mathrm{C}$ translocation intensity (Table 5). The high-yielding genotypes 'Georgia Jet', 'Travis', and selection 75-96-1 had both high ${ }^{14} \mathrm{C}$ translocation rates and high storage root yields. Similarly, high-yielding peanut genotypes (Bhagsari and Brown, 1976) and potato clones (Gawronska et al., 1984) also had higher ${ }^{14} \mathrm{C}$ translocation rates than the low-yielding genotypes.
Correlation coefficients. Storage root yield for 1981, determined every 2 weeks, significantly correlated four out of six times with September CPn (Table 6), but only one out of six with August CPn (data not shown). Canopy photosynthesis for September was also correlated with dry matter storage root yield at final harvest $\left(r=0.54^{*}\right)$ in 1981 and with phytomass $(\mathrm{r}=$ $0.60 *)$ in 1982 .

The high HI of sweet potato indicates that storage roots con- 
Table 5. Storage root yield, roots per plant, and percent ${ }^{14} \mathrm{C}$ translocation of sweet potato genotypes. $^{2}$

\begin{tabular}{|c|c|c|c|c|c|c|c|}
\hline \multirow[b]{2}{*}{ Genotype } & \multicolumn{2}{|c|}{$\begin{array}{l}\text { Fresh storage } \\
\text { root yield }\end{array}$} & \multicolumn{2}{|c|}{$\begin{array}{c}\text { Dry matter } \\
\text { storage root yield }\end{array}$} & \multicolumn{2}{|c|}{$\begin{array}{l}\text { Storage roots } \\
\text { per plant }\end{array}$} & \multirow{2}{*}{$\begin{array}{c}{ }^{14} \mathrm{C} \text { trans- } \\
\text { location } \\
1981 \\
(60 \\
\text { DAP })\end{array}$} \\
\hline & $\begin{array}{l}1981 \\
(135 \\
\text { DAP) }\end{array}$ & $\begin{array}{l}1982 \\
(143 \\
\text { DAP })\end{array}$ & $\begin{array}{l}1981 \\
(135 \\
\text { DAP) } \\
\end{array}$ & $\begin{array}{l}1982 \\
(143 \\
\text { DAP) } \\
\end{array}$ & $\begin{array}{l}1981 \\
(135 \\
\text { DAP) }\end{array}$ & $\begin{array}{l}1982 \\
(143 \\
\text { DAP) }\end{array}$ & \\
\hline & \multicolumn{4}{|c|}{$M g \cdot h a^{-1}$} & \multicolumn{2}{|c|}{ No. } & $\%$ \\
\hline Georgia Jet & 60.0 & $57.9^{\circ}$ & 7.2 & 11.4 & 8.6 & 7.8 & 46.1 \\
\hline Lo 323 & 57.9 & 47.5 & 8.0 & 8.7 & 5.3 & 7.8 & 29.0 \\
\hline $71-63-1$ & 36.9 & 32.4 & 6.8 & 7.1 & 10.3 & 7.0 & 21.2 \\
\hline Centennial & 28.0 & 27.9 & 6.0 & 6.5 & 7.4 & 6.7 & 29.3 \\
\hline Georgia Red & 28.0 & 29.6 & 5.1 & 6.7 & 6.3 & 7.1 & 32.8 \\
\hline Acadian & 21.2 & 8.1 & 3.7 & 1.7 & 3.2 & 2.6 & 24.5 \\
\hline $75-96-1$ & 41.7 & 44.5 & 8.6 & 11.4 & 4.8 & 4.8 & 40.5 \\
\hline L7-3 & 27.9 & 30.9 & 5.8 & 7.0 & 5.5 & 6.3 & 33.3 \\
\hline Travis & 56.2 & 53.3 & 6.8 & 8.0 & 5.9 & 9.3 & 42.7 \\
\hline Earlyport & 34.9 & 34.5 & 7.2 & 8.6 & 10.0 & 11.5 & 35.8 \\
\hline Carolina Nugget & 37.5 & 34.3 & 8.4 & 7.5 & 6.7 & 6.0 & 26.4 \\
\hline Carver & 33.6 & 36.0 & 7.6 & 8.9 & 10.3 & 10.7 & 34.9 \\
\hline Coastal Sweet & 22.3 & 26.1 & 5.0 & 6.8 & 3.8 & 5.8 & 26.4 \\
\hline Nemagold & 29.9 & 26.0 & 7.6 & 6.6 & 9.0 & 7.0 & 34.0 \\
\hline OK-8-85 & 32.2 & 31.5 & 7.0 & 7.3 & 11.9 & 9.1 & 32.5 \\
\hline$\% \mathrm{CV}$ & 18.4 & 26.4 & 17.4 & 32.6 & 27.5 & 29.9 & 43.1 \\
\hline LSD $5 \%$ & 9.6 & 13.0 & 1.9 & 3.5 & 3.3 & 3.1 & NS \\
\hline
\end{tabular}

${ }^{2} \mathrm{DAP}=$ days after planting.

yPercent ${ }^{14} \mathrm{C}$ translocation $4 \mathrm{hr}$ after pulse-labeling for $15 \mathrm{~min}$ with ${ }^{14} \mathrm{CO}_{2}$.

Table 6. Relationship of canopy photosynthesis (CPn), harvest index, and storage root dry matter yield (DMSRY) for 15 sweet potato genotypes to weight of storage roots present on successive dates during the growing season, 1981.

\begin{tabular}{|c|c|c|c|c|c|}
\hline \multirow[b]{2}{*}{$\begin{array}{l}\text { Storage root } \\
\text { sampomling date }\end{array}$} & \multirow[b]{2}{*}{$\begin{array}{c}\text { Days after } \\
\text { planting }\end{array}$} & \multirow{2}{*}{$\begin{array}{l}\text { CPn } \\
8-10 \\
\text { Sept. }\end{array}$} & \multicolumn{2}{|c|}{ Harvest index } & \multirow{2}{*}{$\begin{array}{c}\text { DMSRY } \\
2-8 \\
\text { Oct. }\end{array}$} \\
\hline & & & $\begin{array}{c}13-16 \\
\text { July }\end{array}$ & $\begin{array}{l}2-8 \\
\text { Oct. }\end{array}$ & \\
\hline 13-16 July & 51 & $0.72^{* *}$ & $0.91 * *$ & $0.67^{* *}$ & $0.45^{\mathrm{NS}}$ \\
\hline 27-30 July & 65 & $0.60^{*}$ & $0.75^{* *}$ & $0.44^{\mathrm{NS}}$ & $0.18^{\mathrm{NS}}$ \\
\hline 12 Aug. & 79 & $0.53^{*}$ & $0.55^{*}$ & $0.50^{*}$ & $0.43^{\mathrm{NS}}$ \\
\hline 26 Aug. & 93 & $0.35^{\mathrm{NS}}$ & $0.25^{\mathrm{NS}}$ & $0.72^{* *}$ & $0.53^{*}$ \\
\hline 9 Sept. & 107 & $0.36^{\mathrm{NS}}$ & $0.46^{\mathrm{NS}}$ & $0.77^{* *}$ & $0.69^{* *}$ \\
\hline 24 Sept. & 122 & $0.63^{*}$ & $0.67^{* *}$ & $0.71^{* *}$ & $0.61^{*}$ \\
\hline
\end{tabular}

${ }^{2}$ At final harvest, 1981 .

yStorage root yield data from sampling dates was used to calculate correlations.

NS. "."Nonsignificant or significant at $P=0.05$ or 0.01 , respectively.

stitute the main sink for photosynthate. The lack of correlations between August CPn and storage root yield may be caused by the poor establishment of storage root sinks at that time. Photosynthetic evaluation of sweet potato genotypes may be more relevant when storage roots are in an advanced stage of development (Bhagsari and Harmon, 1982). The correlations of the successively harvested storage root samples with $\mathrm{HI}$ and dry matter storage root yield indicated that the yield potential of the genotypes may be predicted about 80 DAP.

The HI and phytomass were positively correlated with storage root dry matter yield for both experiments (Table 7). This relationship indicates that an increase in HI and phytomass may lead to a yield increase. Fresh storage root yield was correlated with ${ }^{14} \mathrm{C}$ translocation and LAI for the 13 July harvest in 1981.
Table 7. Correlation coefficients $(r)$ between various traits for sweetpotato $(\mathrm{N}=13)$.

\begin{tabular}{lll}
\hline \hline Traits $^{z}$ & Year & $r$ \\
\hline 1) HI (final harvest) vs. DMSRY & 1981 & $+0.59^{*}$ \\
2) Phytomass vs. DMSRY & 1981 & $+0.71^{* *}$ \\
3) FSRY vs. ${ }^{14}$ C translocation & 1981 & $+0.57^{*}$ \\
4) FSRY vs. leaf area index 13 July & 1981 & $+0.54^{*}$ \\
5) HI 13 July vs. HI (final harvest) & 1981 & $+0.62^{*}$ \\
6) HI (final harvest) vs. roots/plant & 1981 & $+0.62^{*}$ \\
7) Phytomass vs. HI (final harvest) & 1981 & $+0.63^{*}$ \\
8) Phytomass vs. DMSRY & 1982 & $+0.77^{* *}$ \\
9) DMSRY vs. HI 30 Aug.-2 Sept. & 1982 & $+0.53^{*}$ \\
10) DMSRY vs. HI (final harvest) & 1982 & $+0.66^{* *}$ \\
11) HI (final harvest) vs. roots/plant & 1982 & $+0.83^{* *}$ \\
\hline
\end{tabular}

${ }^{\mathrm{z}} \mathrm{HI}=$ harvest index; DMSRY $=$ dry matter storage root yield; FSRY $=$ fresh storage root yield.

Ns,,$"$ Nonsignificant or significant at $P=0.05$ or 0.01 , respectively.

Sweet potato Pn was not related to $\mathrm{CPn}$. Similar results were reported for cotton (Gossypium hirsutum L.) (Wells et al., 1988). On the contrary, Pn and CPn were positively correlated in corn (Zea mays L.) (Pearson et al., 1984). The lack of correlation between Pn and CPn in cotton and sweet potato, especially late in the season, may be attributed to their indeterminate growth habit, which results in the presence of some young foliage capable of high Pn even when parts of the canopy are senescing.

Sink strength differed among sweet potato genotypes. Selection 75-96-1, 'Acadian', 'Coastal Sweet', and L7-3 had a similar number of storage roots per plant, but storage root yield was significantly higher for selection 75-96-1 than for the other three genotypes. This disparity suggests that differences in rate of photosynthate translocation to storage roots caused yield dif- 
ferences among these genotypes. This relationship is also in agreement with significant correlations of ${ }^{14} \mathrm{C}$ translocation and fresh storage root yield for 1981. The similar CPn for 'Acadian' and selection 75-96-1 indicated similar photosynthate availability for translocation to storage roots. However, selection 75-961 produced higher yield than 'Acadian', suggesting higher photosynthate translocation to storage roots and root sink strength in selection 75-96-1.

Significant variations appeared in sweetpotato $\mathrm{HI}$ at 50 to 60 DAP. Yield is influenced by HI, as shown by the correlations of HI with yield. The use of $\mathrm{HI}$ as an evaluation tool for sweet potato improvement may be more important for industrial types than for the table types. The evaluation of table type sweetpotatoes emphasizes mainly storability, root shape, market grade, general appearance, and consumer acceptance. These specific criteria may have excluded many high-yielding table-type genotypes as potential cultivars.

Significant variations existed in $\mathrm{Pn}, \mathrm{CPn}, \mathrm{HI}$, and sink strength among sweet potato genotypes. Both photosynthesis and $\mathrm{HI}$ are heritable traits (Harrison et al., 1981; Kawano et al., 1978). Photosynthetic heterosis for $\mathrm{F}_{1}$ cotton plants increased early season growth and CPn (Wells et al., 1988). Identification of elite sweet potato genotypes having high $\mathrm{CPn}, \mathrm{HI}$, and other superior yield-related physiological traits for use as mother plants in a polycross nursery may enhance yield and quality through hybridization, since most sweet potato cultivars are $F_{1}$ hybrids. A similar approach is in use to improve yield and HI of selection 75-96-1.

\section{Literature Cited}

Austin, R. B., C.L. Morgan, and M.A. Ford. 1982. Flag leaf photosynthesis of Triticum aesfivum and related diploid and tetraploid species. Ann. Bet. 49:177-189.

Bhagsari, A.S. 1981. Relation of photosynthetic rates to yield in sweet potato genotypes. HortScience 16:779-780.

Bhagsari, A.S. and R.H. Brown. 1976. Translocation of photosynthetically assimilated ${ }^{14} \mathrm{C}$ in peanut (Arachis) genotypes. Peanut Sci. 3:5-9.

Bhagsari, A.S. and R.H. Brown. 1986. Leaf photosynthesis and its correlation with leaf area. Crop Sci. 26: 127-132.

Bhagsari, A. S., R.E. Webb, S.C. Phatak, and C.A. Jaworski. 1988. Canopy photosynthesis, stomatal conductance and yield of Solarium tuberosum grown in a warm climate. Amer. Potato J. 65:393-406.

Bhagsari, A.S. and S.A. Harmon. 1982. Photosynthesis and photosynthate partitioning in sweet potato genotypes. J. Amer. Sot. Hort. Sci. 107:506-510.

Bouwkamp, J.C. and M.N.M. Hassam. 1988. Source-sink relationships in sweet potato. J. Amer. Soc. Hort. Sci. 113:627-629.
Duncan, W. G., D.E. McCloud, R.L. McGraw, and K.J. Boote. 1978. Physiological aspects of peanut yield improvement. Crop Sci. 18:10151020.

Enyi, B.A.C. 1977. Analysis of growth and tuber yield in sweet potato (Ipomoea batatas) cultivars. J. Agr. Sci., Cambr. 88:421430.

Gawronska, H., R.B. Dwelle, J.J. Pavek, and P. Rowe. 1984. Partitioning of photoassimilates by four potato clones. Crop Sci. 24:10311036.

Gent, M.P.N. and R.K. Kiyomoto. 1985. Comparison of canopy and flag leaf net carbon dioxide exchange of 1920 and 1977 New York winter wheats. Crop Sci. 25:81-86.

Gifford, R.M. and L.T. Evans. 1981. Photosynthesis, carbon partitioning, and yield. Annu. Rev. Plant Physiol. 32:485-509.

Gifford, R. M., J.H. Thorne, W.D. Hitz, and R.T. Giaquinta. 1984. Crop productivity and photoassimilate partitioning. Science 225:801808.

Harrison, S. A., H.R. Boerma, and D.A. Ashley. 1981. Heritability of canopy-apparent photosynthesis and its relationship to seed yield in soybeans. Crop Sci. 21:222-226.

Hofstra, G. and C.D. Nelson. 1969. A comparative study of translocation of assimilated ${ }^{14} \mathrm{C}$ from leaves of different species. Planta 88:103-112.

Kawano, K., A. Amaya, P. Daza, and M. Rios. 1978. Factors affecting efficiency of hybridization and selection in cassava. Crop Sci. 18:373-376.

Lowe, S.B. and L.A. Wilson. 1974. Comparative analysis of tuber development in six sweet potato [Ipomoea batatas (L.) Lam] cultivars: I. Tuber initiation, tuber growth and partition of assimilate. Ann. Bot. 38:307-317.

Pearson, C. J., E.M. Larson, J.D. Hesketh, and D.B. Peters. 1984. Development and source-sink effects on single leaf and canopy carbon dioxide exchange in maize. Field Crops Res. 9:391-402.

Peet, M. M., A. Bravo, D. Wallace, and J.L. Ozbun. 1975. Photosynthesis, stomatal resistance, and enzyme activities in relation to yield of field-grown dry bean varieties. Crop Sci. 15:287-293.

Schapaugh, W. T., Jr., and J.R. Wilcox. 1980. Relationships between harvest indices and other plant characteristics in soybeans. Crop Sci. 20:529-533.

Victorio, R. G., U. Moreno, and C.C. Black, Jr. 1986. Growth, partitioning, and harvest index of tuber-bearing Solarium genotypes grown in two contrasting Peruvian environments. Plant Physiol. 82:103108.

Wells, R., L.L. Schultze, D.A. Ashley, H.R. Boerma, and R.H. Brown. 1982. Cultivar differences in canopy apparent photosynthesis and their relationship to seed yield in soybeans. Crop Sci. 22:886-890.

Wells, R., W.R. Meredith, Jr., and J.R. Williford. 1988. Heterosis in upland cotton: II. Relationship of leaf area to plant photosynthesis. Crop Sci. 28:522-525.

Zelitch, I. 1982. The close relationship between net photosynthesis and crop yield. Bioscience 32:796-802. 